\title{
Chapter 4: What is a whale? Moby-Dick, marine science and the sublime
}

\author{
$\S 1$. Why Moby-Dick? An introduction
}

Moby-Dick (1851/1931) is a magnificent novel, an American epic, a literary encyclopaedia, a monument of language. Jean-Paul Sartre (1941/1977) called it a Summa, a gigantic, monstrous, antediluvian book. One may read Moby-Dick for several reasons, and from several perspectives: as a novel of adventure, a psychological case history casting an obsessed sea captain, an anthropological study of nineteenth century maritime life, or a fascinating example of Bakhtinean "heteroglossia". ${ }^{1}$ Whenever reference to Moby-Dick is made, the first thing that will come to mind, no doubt, is the novel's fantastic plot, more spectacular than tragic, when the great White Whale at last destroys the destroyer of its species. Indeed, Moby-Dick can be read as an affidavit, a persistent effort of Ishmael - its narrator - to convince us of the fact that things like that can really happen - although in the end hardly anyone will believe him.

In this chapter, however, Moby-Dick will be read as a literary document that sets out to tell us something about maritime nature, about the wide, unshored, oceanic expanses and its most eminent inhabitant, the whale - the great Sperm Whale to be exact. Melville's novel constitutes an important file, a chapter in animal history, written in the middle of the nineteenth century, when Darwin was about to publish his Origin of Species. Moby-Dick is a document that pretends to answer the question What is a whale? Or rather, it stages a struggle between several incompatible answers, yielded by incompatible perspectives on marine life, mutually challenging and criticizing one another. Moreover, these answers entail different ethical judgements on the moral status of the whale and on the moral propriety of whaling.

Three perspectives, three ways of answering the question of the whale, as fleshed out in the novel, will be taken into consideration in this Chapter: that of the whaler (or "whaleman" as Melville calls him), the scientist, and the philosopher. In this introduction I will sketch them in broad outline, before submitting them to a more careful examination in subsequent sections.

To the nineteenth century whaler, whales and their environment offered ample opportunity for a life of adventure and hazardous encounters. But first of all, they provided him with a source of income. The sordid, time-consuming business of whaling basically came down to transforming incredible amounts of organic blubber into merchantable oil. In his magnificent head, the Sperm Whale kept the precious substance from which he derived his name, spermaceti, that used to be manufactured into medicinal products. ${ }^{2}$ Finally, whale bones and teeth were used as raw materials for contrivances of various kinds.

To the nineteenth century scientist, the sea and the whale basically constituted an enigma. In the $1850 \mathrm{~s}$, marine scientists were still struggling with obscure phenomena such as tides and currents, ${ }^{3}$ the existence of deep sea life and the chemical composition of sea water

\footnotetext{
${ }^{1}$ According to Bakhtin (1988), a true novel is a polyphonic, multi-voiced interplay of languages, accents and dialects. This is exemplified by the following quote taken from Moby-Dick: "Something of the salt sea yet lingered in old Bildad's language, heterogeneously mixed with Scriptural and domestic phrases..." (p. 813).

2 Spermaceti literally means "whale sperm", which was what "landlubbers" (incorrectly) believed the white, greasy, odorous substance to be.

3 "The secrets of the currents in the seas have never yet been divulged, even to the most erudite research..." (p.
} 
(Deacon 1971). As for whales, naturalists from Aristotle onwards had clearly been puzzled by them. Aristotle noticed that whales and dolphins were viviparous and that they had breasts and lungs (489b4, 521b24) and therefore, he set them aside from other sea-animals. Yet, although he recognized several similarities with terrestrial quadrupeds, it was Linnaeus himself who finally decided to associate these life forms with one another - an important decision, because it resulted in a change of name: mammals instead of quadrupeds (Nordenskiöld 1928/1946, p. 213). But precisely how such a gigantic mammal was able to survive and find its way in the depths and immensities of the oceanic world, remained utterly incomprehensible.

Finally, from a philosopher's perspective, the ocean functioned as a powerful image, as in the case of Kant, who incorporated the image of the wide, maritime expanses into his theory of the sublime. In the case of Nietzsche, who regarded himself a spiritual descendant of Columbus (Janz 1978, p. 247) and compared his philosophical project with a sea journey, ${ }^{4}$ the ocean functioned as a metaphor for widening one's perspective and expanding one's horizons, as exemplified by his aphorism "Embark" in Die fröhliche Wissenschaft ["The Gay Science"]:

[W] hat is needful is a new justice! And a new watchword. And new philosophers. The moral earth, too, is round. The moral earth, too, has its antipodes. The antipodes, too, have the right to exist. There is yet another world to be discovered - and more than one. Embark, philosophers! ${ }^{5}$

This summons clearly resonates with the "archetypal image" associated with water as a basic element, discussed in Chapter 2, water as the element of freedom, of mobility, of widening one's horizon. Although Nietzsche himself refrained from doing what he summoned others to do, scientists like Darwin and novelists like Melville actually went to sea. Darwin, although regarded by Nietzsche as an arid and mediocre mind, ${ }^{6}$ exposed himself to the experience of a long-term trans-oceanic voyage in the course of which he did discover new worlds, new justifications, new moral watchwords even ("struggle for life") that were to have a tremendous impact on science, philosophy and even culture at large.

Other perspectives are present in Moby-Dick as well, such as the theologian's one, depicting the whale as the biblical Leviathan and the ocean as that part of the world where the great flood never abated. Indeed, the interpretation of marine phenomena in Biblical terms is more or less omnipresent in the novel and also resounds in the views and language of the philosophical sailor and story-teller Ishmael.

But what about the novelist's whale? Actually, there is not one novelist's whale. Ishmael-the-narrator unmistakably sides with the whaler's point of view, but Melville-the-

869).

${ }^{4}$ See for example his Letter to Erwin Rohde of February 22, 1884: "In the meantime, I pursue my course. It is really a journey, a sea journey..." ("Inzwischen gehe ich meinen Gang weiter, eigentlich ist's eine Fahrt, eine Meerfahrt...").

5 “'E]ine neue Gerechtigkeit tut not! Und eine neue Lösung! Und neue Philosophen! Auch die moralische Erde ist rund! Auch die moralische Erde hat ihre Antipoden! ... Es gibt noch eine andere Welt zu entdecken - und mehr als eine! Auf die Schiffe, ihr Philosophen!” [Die fröhliche Wissenschaft, § 289]. The same basic image is present in $\S 124$ ("We have left the land and have embarked..."), § 283 ("Live dangerously... Send your ships into uncharted seas...") and Appendix ("Toward new seas... Without plan, into the vast open sea I head my Genoese ship" - note that Columbus came from Genoa).

6 "For scientific discoveries of the type of Darwin's a certain narrowness, aridity and industrious diligence ... may not be a bad disposition" (Nietzsche 1980, § 253). 
author is interested in, and tries to do justice to, a plurality of voices. Various idiolects are allowed entrance into his multi-lingual novel. On some occasions, for example, the whale is viewed from a purely economic aspect, and the novel informs us about the incredible quantities of oil that may be extracted from one whale, while the whale's head is called the Heidelbergh Tun, a great "tierce" replenished with five hundred gallons of spermaceti ( $\mathrm{p}$. 963/964). At other times, however, the whale emerges as an aesthetical phenomenon, and we find the spectators allured by the "gentle joyousness", the "mighty mildness of repose in swiftness" with which the gliding great whale is invested (p. 1086). Even within a particular perspective, such as the scientific one, the novel's language tends to oscillate between, for example, a mechanistic account (telling us that the aorta of a whale is larger in the bore than the main pipe of the water-works at London Bridge ${ }^{7}$ ) and a more or less vitalistic one, explaining how by breathing, the whale withdraws from the air a certain element imparting to the blood its vivifying principle; and how, during his sojourn in the depths, he carries "a surplus stock of vitality in him" (p. 982).

As for the novel's dramatis personae, Ishmael is initially a light-hearted adventurer who wants to see the world and find out by experience what whaling is. He is enlisted on the Pequod, with Ahab for a captain: an introvert, demonic maniac, who lost a leg while trying to capture Moby-Dick on a previous voyage and is now obsessed with this one desire: to “dismember his dismemberer" (p. 860). Queequeq, one of the Pequod's harpooners, is casted as a noble savage. We are told, for instance, that his head is reminiscent of George Washington's head: “Queequeg was George Washington cannibalistically developed” ( $p$. 789). The Pequod takes sail from the famous East-Coast whaling Port of Nantucket. Its inhabitants, we are informed, are outstanding whaling experts who for centuries cruised the oceans to give chase to the great Leviathan. In the case of the Pequod, however, the whalingvoyage is transformed into a disquieting crusade against Moby-Dick, a white Sperm Whale of astonishing magnitude, the most appalling of all brutes, notorious for his intelligent malignity. In the meantime a considerable number of whales are captured, but Moby-Dick remains the Pequod's "final and romantic object" (p. 887). When, in the tropical Pacific, the fatal encounter finally takes place, it all ends with a fantastic, incredible catastrophe. After killing Ahab, Moby-Dick manages to sink the vessel. Ishmael is the sole survivor, the last human being in a flooded world.

But Ishmael's account is not simply another fantastic whaling-story. From the very outset it purports to be a quasi-scientific manual on whaling and on whales, a monograph on cetology - Cetus being the Latin name for whale. ${ }^{8}$ Similar cetological works had been published in previous years, such as Thomas Beale's Natural history of the Sperm Whale and (above all) William Scoresby's Account of the arctic regions with a history and description of the northern whale fishery. Melville knew most of these books and extensively borrowed from them (Vincent, 1992; Parker, 1992). Moby-Dick is in fact a literary parody on this genre that was quite popular at the time. ${ }^{9}$ From an epistemological point of view, these documents constitute an intermediary genre between official science and the "folk biology" of practical

\footnotetext{
7 The water roaring in its passage through that pipe is "inferior in impetus and velocity to the blood gushing from the whale's heart" (p. 754).

8 The order of the cetaceans includes whales, dolphins and porpoises and is taxonomically subdivided into odontocetes (toothed whales, dolphins, porpoises ) and mysticetes (baleen whales). The sperm whale is a toothed whale, notorious for hunting giant squid in the deep, dark, inaccessible ocean regions.

9 At times, he uses lofty scientific formula - "It will have been seen that...", "as has been elsewhere set forth...", etc. - but the general mood is one of parody and laughter. Indeed, "Moby-Dick reads like a formal essay, except that Melville's tone is mocking and his procedure high-spirited" (Vincent 1992). Moby-Dick provides ample material in support of Bakhtin's theory that the novel parodies official speech genres, including that of science.
} 
men. In the writings of Beale, Scoresby and others, two contemporary ways of acquiring knowledge on whales - namely practical experience and systematic research - tend to converge into documents that can be regarded as epistemological hybrids. In Moby-Dick, however, the basic tension between scientific and practical knowledge is amplified, intensified. For its narrator it is clear that a whaler's understanding of the whale is of a completely different nature than the scientific one. Whereas whalers draw from their personal acquaintance with the phenomena of maritime life, the scientist relies on careful, systematic observation (notably dissection of stranded whales). Ishmael unmistakably acts as the whaler's advocate. His practical cetology is emphatically anti-scientific.

This chapter aims to be an analysis in depth of the epistemological aspects of Melville's novel. In the next section, the whaler's epistemology of self-exposure will be confronted with the scientist's epistemology of self-restraint. To what extent can science truthfully disclose the wondrous phenomena of maritime life in general and of a whale's life in particular? Most notably, I will focus on Ishmael's criticism of the scientific practice of classification, building on our discussions in Chapter 3.

Subsequently, I will turn to philosophy and its epistemology of meditation. Most notably, I will focus on the way the experience of the sublime is represented in the novel. Gradually, however, this comparison will reveal the extent to which epistemological choices and differences also determine our moral experiences and assessments concerning whales. Indeed, Moby-Dick reveals the close affinity between epistemology and ethics. Melville's novel allows us to understand how the whaler's appreciation of the whale differs from that of the scientist, not only in terms of epistemology, but also in terms of ethics. The conditions created by the practical, the scientific and the philosophical way of perceiving and experiencing whales are bound to generate diverging moral affinities. This is quite apparent, for example, when the issue of the possible extinction of the whale is raised. What we may learn from Moby-Dick is that our position regarding such issues is determined to a large extent by our epistemological convictions, as well as by the sources and practices we tend to rely on when answering the question "What is a whale?" In other words, Melville's novel can be read in various ways, but it is first of all an exercise in comparative epistemology.

\section{$\S 2$. What is a whale? The epistemology of self-exposure versus the epistemology of self-restraint}

As already indicated in Chapter 3, the whaler's knowledge of whales and their environment is characterized in Moby-Dick as "the real living experience of living men" (p. 869). Only whalers really and truly know what a whale is, and only a whaler's picture of a whale conveys a truthful idea of the living animal as seen by his living hunters. Scientists are basically regarded as inexperienced. Most of them have seldom seen, let alone hunted whales. The basic epistemological stance of practical cetology is self-exposure. The only way to get to know the whale is to expose oneself to the experience of a whaling voyage:

"How vain and foolish, then, thought I, for timid untravelled man to try to comprehend aright this wondrous whale, by merely poring over his dead attenuated skeleton... No. Only in the heart of quickest perils; only when within the eddyings of his angry flukes; only on the profound unbounded sea, can the fully invested whale be truly and livingly found out" (p. 1032). 
A whale-ship, Ishmael assures us, was his Yale College and his Harvard (p. 826). And although he agrees that a professional hunter's account may suffer from exaggerations, he nonetheless emphasizes that on certain occasions, the apparently fabulous will be "fully equalled by the realities of whaling" (p. 869).

Ishmael claims to have read a substantial amount of official zoological publications on whales, but he seldom finds them very helpful when it comes to understanding whales. Utter confusion exists among the natural historians of this animal, he argues, and they themselves quite readily admit it - an "impenetrable veil" is said to cover all knowledge of the cetacea (p. 838). For Ishmael, the cause of this confusion is not difficult to point out. Many are the men who have written of the whale, he tells us, but only a few ever saw living whales, and only one of them (William Scoresby) was a professional harpooner and whaler. Most landsman (and this includes most naturalists) are completely ignorant of some of the plainest and most palpable wonders of the oceanic world. Of a particular species of whales (namely the Killer Whale) Ishmael tells us that "little is known to the Nantucketer, and nothing at all to the professed naturalist" (p. 844). As to the great Sperm Whale, he assures us that his is still an "unwritten life" (p. 839). It even seems impossible to visualize the whale. The great Leviathan defies any representation. He is that one creature in the world which remains unpainted. There is no earthly way of finding out precisely what the whale looks like. Again, the only mode in which even a tolerable idea of his living contour can be derived, is "by going a-whaling yourself" (p. 921). And the only genre that may be able to convey this type of knowledge truthfully is the novel. Like Ibsen in The lady of the sea, Melville seems to subscribe to the idea that there are forms of knowledge about the sea and its inhabitants that are more intimate and natural somehow than formal knowledge and cannot be articulated in scientific terms. Only literary genres can document them in a sensitive and convincing way.

Thus, according to Ishmael, cetology can only achieve its aims by abandoning the epistemology that entails careful, protracted scholarly work in favour of self-exposure. After having ascertained that a picture of a whale contained in a book by the naturalist Frederick Cuvier is seriously flawed, Ishmael pardons the author by pointing out that he never had the benefit of a whaling voyage. All pictures in "a scientific systemized whale book" by Lacépède are judged as incorrect (p. 920). And when in another volume a surprisingly correct engraving is encountered, Ishmael concludes that the person responsible for it "was either practically conversant with his subject or else marvellously tutored by some experienced whaler" (p. 922). Still, some serious fault might be found with the anatomical details of this whale, Ishmael admits, "but let that pass" (idem). Official science, taking its drawings mostly from stranded specimen, is a deficient practice. For Ishmael, even the carefree pictures of whales painted by retired sailors on boards, boxes and whale-teeth are usually more adequate than the most careful drawings in scientific publications.

Thus, self-exposure is the royal path to knowledge. To Captain Peleg, who enlists him on the Pequod, Ishmael explains that he wants to find out by experience what whaling is, that he wants to see the ocean with his own eyes (p. 802). Peleg suggests that he might step forward and take a peep over board, where the open ocean can readily be seen: an unlimited prospect, exceedingly monotonous. "Well, what's the report?" Peleg asks him, "what did ye see?". Not much, is Ishmael answer, nothing but water and the horizon. But in order to really see the ocean, one has to dwell on it for months, for years preferably.

The lives of whales are obscured by the methods of "professed naturalists" and scientific "cetologists". As soon as a scientific stance is taken, the real living whale seems to disappear. As soon as we are informed about the number of vertebrae in the whale's vertebral 
column, or about the exact latitudes and longitudes of the whale's migratory routes, the real living whale seems lost. The epistemology of science is one of self-restraint, rather than selfexposure. From a scientific point of view, sailors (particularly whalers) are to be regarded as a notoriously unreliable source of information on whales. ${ }^{10}$ Their basic flaws are capriciousness and (above all) a tendency towards exaggeration. They all too readily allow themselves to be fascinated by the marvellous. "In maritime life", Ishmael assures us, "far more than in that of terra firma, wild rumours abound, wherever there is any adequate reality for them to cling to. And as the sea surpasses the land in this matter, so the whale fishery surpasses every sort of maritime life, in the wonderfulness and fearfulness of the rumours which sometimes circulate there" (p. 867). As whalers are "by all odds the most directly brought into contact with whatever is appallingly astonishing in the sea" (idem), Ishmael acknowledges that their reliability should be counted even less than that of the other sailing professions. Face to face, they eye the sea's greatest marvels. Therefore, it is only by exaggerating the factually known that one can approximate something like the real living experience of whalers. Thus, conjectures are readily turned into possibilities, and possibilities into established facts.

In Chapter forty-five Ishmael presents us with a formal Affidavit regarding the question whether a sperm whale can really destroy a whaling vessel. He begins by saying that he cares not to perform his task methodically, like a "professed naturalist" would, but contents himself with producing the desired impression by citing certain a limited number of citations, practically or reliable known to him as a whaler. From these citations, he takes it, the conclusion aimed at will naturally follow of itself (p. 881). His subsequent argument is indeed worked out in accordance with this procedure. One of the problems facing the whaler is that his experiences may often seem incredible to landlubbers. People ashore only vaguely surmise what an enormous creature a Sperm Whale really is. In order to establish that a member of this species may be sufficiently powerful, knowing and malicious to destroy and sink a large ship, several items of evidence are cited. In the year 1820 the ship Essex of Nantucket was attacked by a huge Sperm Whale. "I read [the captain's] plain and faithful narrative", Ishmael assures us, "and conversed with his son, and all this within a few miles of the scene of the catastrophe" (p. 883). An extract from the captain's own account runs thus:

"At all events, the whole circumstances taken together, all happening before my eyes, and producing, at that time, impressions in my mind of decided, calculated mischief, on the part of the whale (many of which impressions I cannot now recall), induce me to be satisfied that I am correct in my opinion" (idem).

Mention is made of other evidence "one way or another known to me" and finally Ishmael points out that the marvellous event is not only corrobated by present facts, but that similar marvels occurred in previous ages. Procopius, sixth Century A.D., by the best authorities considered a most trustworthy and unexaggerating historian, testified how a great sea monster destroyed vessels in the sea of Marmora. According to Ishmael, this certainly must have been a whale, and he is even "strongly inclined" to think a Sperm Whale. For although Sperm Whales are never seen in the Mediterranean, further investigation brought out that not so long ago a Commodore Davis found a skeleton of a sperm whale on the Barbary coast. Ergo, Procopius' sea-monster must in all probability have been a sperm whale. In this manner,

10 "All sailors of all sorts are more or less capricious and unreliable" (p. 887). 
Ishmael gives us an impression of a whaler's method of argumentation. ${ }^{11}$

From a Bachelard-like point of view, it is not too difficult to subject Ishmael's account to a "psychoanalytical" assessment. As was pointed out in Chapter 2, Bachelard follows Jung in his distinction between the two modes of thinking: formal (or discursive) and imaginative thinking. Whereas the former evolves on the basis of formal logic and the causality principle, the latter relies on association and anecdotal information. It is obvious that Ishmael's cetology belongs to the second format. This means that his epistemological differences with the various forms of scientific academic discourse are of a very fundamental

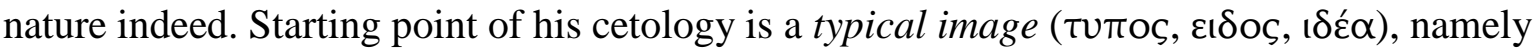
the monster archetype, the icon of an incredibly huge and even veracious whale. It is an obstinate idea: the biblical Leviathan, that is also emphatically present in various pre-modern scientific sources, such as Procopius, and in the stories of sailors all times. Ishmael's treatment of empirical data is clearly in accordance with this imaginative mode of thought. He eagerly cites sources that support his basic idea, while ignoring others. Contradictory evidence simply cannot be true. It is at odds with the very basic, eradicable idea that inspires him, that imprinted itself in his psyche - his basic truth. Scientific discourse can never live up to, never do justice to this basic, inviting, indeed: alluring image. From the point of view of imagination, as a mode of thought, science is bound to disappoint us. Indeed, as an iconoclastic practice, it remains suspicious towards the images of the marvellous, aiming to replace them with quantitative data, numbers, biological terminology, chemical nomenclature and so on. Ishmael is disappointed by nineteenth century zoology much as Victor Frankenstein was disappointed by nineteenth century chemistry. Take for example Victor's lamentation already cited in Chapter 1: "The ambition of the [modern] enquirer seemed to limit itself to the annihilation of those visions on which my interest in science was chiefly founded. I was required to exchange chimeras of boundless grandeur for realities of little worth" (p. 306). Ishmael's experience is remarkably similar. Yet, unlike Victor, he stubbornly refuses to subject himself to an epistemological conversion. Or perhaps we should say that, given his working-class background, he simply was not granted the privilege to really expose himself, other than in a toilsome and autodidactic manner, to the ideas of modern science. He was exposed to conditions (the world of manual, industrial labour) that differed significantly from those of Frankenstein (the bourgeois world of books, poetry, cultural travel and refined experience) and this may have resulted in their diverging epistemological trajectories.

In her impressive and superbly documented history of the marine sciences, Margaret Deacon (1971) elaborately reflects on the epistemological tension between scientific and practical knowledge, tracing it carefully through history, although (quite unlike Ishmael) Deacon rather sides with the scientist's point of view. From Pliny and his contemporaries onwards, Deacon argues, throughout the roman and medieval period, and even during the Renaissance, marine scholars used to taken what she calls a "literary" approach to maritime phenomena, reading, citing and assembling extracts from various sources, producing encyclopaedic compilations of views borrowed from various documents, with the result that knowledge of natural phenomena such as currents and tides was usually much more accurate

\footnotetext{
${ }^{11}$ Jules Verne wrote a novel that shares some similarities with Melville's (Les histoires de Jean-Marie Cabidoulin, published In 1901), - although in Verne's case the narrator sides with the scientific view, rather than with the stories and anecdotes of whalers. Nonetheless, the same types of discussion on sea-animals of monstrous proportions are addressed, against the backdrop of the same epistemological conflict between formal and factual lines of thinking versus imaginative and narrative ones, between practices of classification versus story-telling.
} 
among (illiterate) seamen than among scholars. The people who practically used the sea, however, often did not transfer their accumulated knowledge to paper. While medieval sailors were often well informed about those features of the sea which were relevant to their profession, medieval and early modern writers seldom had any practical knowledge of the phenomena they discussed. The limited number of "solid facts" that were introduced from time to time, were invariably derived from the practical experience of sailors.

It was not until the seventeenth century that marine scientists began to appreciate the importance of first-hand examination and observation. A collaboration between scholars and sailors ensued. Sailors were now asked to collect and record information concerning marine phenomena in the journals of their voyages. At several occasions, the Royal Society published Directions for seamen, counting on the scientifically oriented sailor to collect and record oceanographic information. Such measurements would gradually allow the mapping of so amorphous an element as the ocean (p. 84).

Initially, Beacon tells us, scientists tended to distrust the ability of sailors to make objective observations, almost as much as sailors scorned the complacency of landlubbers. But half-way the nineteenth century - the era of Moby-Dick - the prospects for overcoming this tension became more favourable. Gradually, the collaboration between scientists and sailors improved.

Already in 1769 (or 1770) the importance of a dialogue between scientists and sailors became evident. In that year, Benjamin Franklin noticed that mail packets sailing from Plymouth to New York were taking two weeks longer than the American merchantmen sailing from London to Rhode Island. He mentioned this to Captain Folger, of Nantucket, and was told that this was because the packet boats were unaware that they were sailing against the Gulf Stream. American whalers who hunted the whales on both sides of the current had done their best to enlighten them, but their advice had been disregarded. At Franklin's request, Folger marked the course of the current on a chart, and with the publication of it, people at last became familiar with the concept of the Gulf Stream.

Several concrete examples of collaborations between sailors (including whalers) and scientists are pointed out in Deacon's book. Captain William Scoresby, who also figures in Moby-Dick, was a whaler who published extensively on meteorology - his Account of the Arctic regions has already been mentioned. This book was a whaling manual written by "a genuine whaler gifted with scientific caution and restraint" (Vincent 1992). ${ }^{12}$ Other sailors who greatly contributed to the development of marine science were, for example, Robert Fitzroy of H.M.S. Beagle, who systematically recorded observations in a geographical journal, and John Murray, who joined a whaler as a surgeon and later became an expert on deep sea biology. Sailors were allowed to contribute to science insofar as they adhered to its basic epistemological premises and educated themselves in viewing the ocean in accordance with scientific methods. It took some time before they had familiarized themselves with the protocols and procedures recommended by modern science. By and by, the logbooks and journals were emptied of their narrative content and filled instead with columns, tables, measurements, coordinates - in short: with symbolical data, with numbers.

Ishmael's cetology can perhaps be regarded as a protest against this recruitment of whalemen for the scientific cause, and as a rehabilitation of precisely those forms of knowledge that are bound to be erased by these new types of registration, new techniques for keeping records. Moby-Dick is, one might say, an epistemological mutiny.

From an epistemological point of view, at least one claim made by Ishmael seems

12 In Moby-Dick, Scoresby's scientific exactitude is ridiculed. 
highly questionable, namely the claim that his cetology is based on "the visible whale", on on-site experience. Rather his methodology seems to fit into Deacon's description of the "literary" approach, building huge collections of extracts and anecdotes, complemented with a limited amount of direct observation. I will follow up on this in the next section.

\section{$\S 3$. On classifying whales}

One particular scientific issue receiving ample attention in Moby-Dick is that of classifying the whale. Ishmael distances himself from the uninspiring output of official science, containing so little "original matter", in order to work out a "popular comprehensive classification" of his own (p. 839). A ponderous endeavour indeed, amounting to "the classification of the constituents of a chaos" (p. 838). But, he assures us, "I have swam through libraries and sailed through oceans; I had to do with whales with my visible hands, and I will give it a try" (p. 839).

The basic question is whether a whale is a mammal or a fish. Two official cetological definitions of a whale are cited: Cuvier ("The whale is a mammiferous animal without hind feet", p. 754), and Linnaeus ("I hereby separate the whales from the fish; on account of their warm bilocular heart, their lungs, their moveable eyelids, their hollow ears, and penem intrantem feminam mammis lactantem", p. 839). To a whale-wise practical cetologist, this the identification of the Sperm Whale as a mammal - is unacceptable. How can the most eminent of all sea animals be something other than a fish? In fact, Ishmael consulted Simeon Macey and Charley Coffin, both of Nantucket, for their judgement, and they united in the opinion that the reasons set forth by official science were altogether insufficient, or even humbug (p. 839). Ishmael himself takes "the good old fashioned ground" that the whale is a fish, and calls upon "holy Jonah" to back him. This is how he defines a whale and labels him "for all time to come": "A whale is a spouting fish with a horizontal tail. There you have him..." (p. 840). And he adds: "By the above definition of what a whale is, I do by no means exclude from the leviathanic brotherhood any sea creature hitherto identified with the whale by the best informed Nantucketers; nor, on the other hand, link it with any fish hitherto authoritatively regarded as alien" (idem).

Ishmael admits that his "contracted" definition, said to result from "expanded meditation", lacks "minute anatomical descriptions" (p. 839). It relies on the immediate, visual aspect of the whale as such, in his entire bodily volume, on Anschauung, so to speak. It constitutes what could be called a phenomenological alternative to the dissecting practices of official science. Yet, on closer examination, Ishmael's definition cannot be said to result from "uncontaminated" experience alone. On the contrary, more than on first-hand experience, on "the living experience of living men" as he calls it, it relies on written documents, on theories, on the opinions of authorities, such as the Book of Jonah and the witty "experts" from Nantucket, - and, eventually, it relies on a basic idea, a basic image. Confirmed more or less by a number of dramatic experiences, but not based on systematic research. In order to find support for his idea, Ishmael's cetology borrows from literary sources, such as Procopius and the Bible - a way of practicing natural science that had been rendered obsolete by Linnaeus, Cuvier and others. His cetology may be called pre-Linnaean. It adheres to the epistemological premises, the "historical a priori" as Foucault (1966) called it, of a previous epoch, namely the Renaissance. Indeed, the similarities with pre-Linnaean documents, as analyzed by Foucault, are remarkable. The typical set of items listed in natural histories before Linnaeus and Cuvier, can be found in Ishmael's account as well: the names of whales 
in different languages (Hebrew, Greek, Latin, etc.), references to the whale in the Bible (Jonah, Job, Isaiah, Ezekiel) as well as in outstanding works of art (Hamlet, King Henry, Rabelais, Paradise Lost, etc.), stories about famous, fabulous whales (Rinaldo Rinaldini, Timor To, New Zealand Jack, Morquan, Don Miguel) ${ }^{13}$ and other litteraria, emblematic representations of whales, ${ }^{14}$ information about medical properties of certain whale products (such as spermaceti), anthropomorphic descriptions ("the Hump Back Whale is gamesome and lighthearted", "the Black Fish carries an everlasting Mephistophelean grin", etc.). As Foucault points out, this method for defining natural entities relies to a significant extent on imagination and association, i.e. on the logic of similarities and resemblance. ${ }^{15}$

As a typical pre-Linnaean document, Ishmael's account fails to make a clear distinction between the various sources he uses, such as first-hand observation, hearsay and literary documents. All these materials are simply piled together. From the point of view of science, Ishmael's cetology constitutes a regression, so it seems. It eagerly borrows from literary sources, quite in accordance with the "literary method" that had been in vogue until the middle of the eighteenth century. From Linnaeus onwards scientists had been working hard to strip their object of its textual layers, allowing it to appear naked as it were, collecting factual data rather than texts. ${ }^{16}$ Ishmael, however, persists in unsystematically combining personal observations with extracts of all sorts. In the libraries of whaling he recovers the sediments and residues of centuries of Historia animalorum, in combination with input from the fable literature. With his exegetic readings of Jonah and other canonical (or less canonical) works, Ishmael's cetology comes much closer to the biblical zoology (zoology as a special branch of theology and biblical studies) as it still flourished far into modernity, even up to "Paley's theology", quoted by Ishmael -, than to the marine biology of his day.

Modern science is basically iconoclastic. It destroys the image of the object as a whole, as a Gestalt, in order to replace it by series of numbers and measurements (Foucault 1966, p. 150; Lacan 1981, 1994). But Ishmael clings to his fascinating image of the whale, which in many respects remains a very traditional icon, the biblical Leviathan of old. One cannot say that the whaler's whale in Moby-Dick is the real whale. Rather, like the snowwhite quadruped in the royal standard of Siam and the Hanoverian flag (p. 873), Ismael's heroic whale is a more or less imaginary animal, a fabulous heraldic iconization, rather than a biological species.

\section{$\S 4$. Whaling and philosophy: the meditating sailor}

While Ishmael's attitude towards natural science is outspokenly hostile, his attitude towards philosophy is much more sympathetic. The philosophy he has in mind, however, is of a (pseudo)-platonic, mystifying, meditative type: "Meditation and water are wedded for ever", he tells us (p. 760). Going to sea is Ishmael's way of becoming a philosopher. ${ }^{17}$ All deep

\footnotetext{
13 These are whales "as well known to the students of Cetacean history as Marius or Sylla to the classic scholar" (p. 882).

${ }_{15}^{14}$ Cf. "les blasons où ils figure" (Foucault 1966, p. 141)

15 «[L]a ressemblance se situe du côté de l'imagination ou, plus exactement, elle n'apparaît que par vertu de l'imagination » (1966, p. 83).

16 “Toute le language déposé par le temps sur les choses est repoussé... C'est la chose elle-même qui apparaît" (Foucault 1966, p. 142).

17 His pagan friend Queequeg does not need such an experience, for he is always content and equal to himself, a (Stoic) philosopher from birth (p. 789).
} 
thinking is but "the intrepid effort of the soul to keep the open independence of her sea; while the winds of heaven and earth conspire to cast her on the treacherous, slavish shore" (p. 823) - the shore of official science and of the "cosmopolite philosopher" (p. 824). In the howling infinite landlessness resides "the highest truth, shoreless, indefinite" (p. 823). Again,

Ishmael's view of philosophy reflects the elementary images associated with water, such as freedom of movement and openness of thought.

Of special interest in this respect are his reports of his experiences in the mast-head. The mast-head is described as a "contrivance" (p. 852) for meditation. It is to a philosophical sailor what the laboratory is to a scientific landsman. To a meditative man, the mast-head is simply delightful. There you stand, lost in the infinity of the sea, amidst a sublime uneventfulness. Standing in the mast-head, a place deprived of all comfort, is an ascetical technique for temporarily isolating oneself. Indeed, the basic epistemological maxim of Ishmael's philosophical practice is isolation, as a basic condition for meditation. Thus, the sailor becomes a "Platonist" (p. 853), an absent-minded philosopher. He even runs the risk of losing his identity, taking the mystic ocean at his feet for the visible image of that deep, blue, bottomless soul, pervading mankind and nature (p. 854), - a description in which again an elementary, archetypal image can be recognised. The mast-head is the place where the via practica of whaling imperceptibly passes over into the via contemplativa of philosophy. ${ }^{18}$ But alas, the truth as it is discerned by a meditative sailor hardly allows systematic articulation. The wisdom of the mast-head is bound to cloak itself in silence. "Wonderfullest things are ever the unmentionable" (p. 823).

Moby-Dick is, if anything, a philosophical novel. A considerable number of philosophers are mentioned: Pythagoras, Plato, the Stoics, Seneca, Melanchthon, Hobbes, Montaigne, Bacon, Descartes, Spinoza, Pascal, Locke, Rousseau, Bentham, Kant. The whale's magnificent head is compared to the heads of Plato, Locke and Kant, its skeleton to that of Bentham. Sailing with a Sperm Whale's head hoisted on the starboard, and a Right Whale's on the larboard side, it seems as if the Pequod had hoisted in Locke's head on one side, and Kant's head on the other (p. 957). But like all true philosophers, the captured and hoisted whales remain deeply silent. Their front displays utter indifference towards the world. "Speak, thou vast and venerable head", Captain Ahab mutters one night, "speak, mighty head, and tell us the secret thing that is in thee. Thou hast dived the deepest. There, in that afwul water-land, there was thy most familiar home. In deep midnight, $\mathrm{O}$ head, thou hast seen, and not one syllable is thine" (p. 947). But even if a whale's head could speak, this type of experience cannot be articulated in a discursive manner. It is the experience of the real (Lacan), "das Es" (Freud), of diffuse, unstructured nothingness. The whale really seems to belong there. He remains self-possessed, in tropical as easily as in polar waters, thus constituting something of a philosophical ideal: "Oh, man! admire and model thyself after the whale!", Ishmael exclaims, "Do thou, too, live in this world without being of it. Like the great dome of St. Peter's, and like the great whale, retain, $\mathrm{O}$ man! in all seasons a temperature of thine own" (p. 945). The whale is both an exemplification and a symbol of the sublime.

A considerable number of philosophical issues are being addressed. A prominent one, discussed on more than one occasion, is the question whether the whale (most notably MobyDick himself) is simply to be regarded a "dumb brute" (p. 857, 876, 972), or rather an "intelligent agent". On the one hand we find it stated that Moby-Dick is an active, knowing whale, an animal acting with aforethought, out of intelligent malignity, a judiciously

18 A certain Captain Sleet used the mast-head as a contrivance for systematic scientific experiments (p. 853), notably for examining compass deviations. But to Ishmael, much more a philosopher than a scientist, it is a place for meditativeness. 
malicious agent, inflicting decided, calculated mischief on his foes, with deliberate designs of destruction. On the other hand we are told that the whale is a dumb brute who acts out of blind instinct and rage. Apparently, the latter view is corrobated by anatomy, that is: by the "wonderful comparative smallness" (p. 970) of his cortex. For under the long floor of the crater of his skull reposes "the mere handful of this monster's brain" (p. 969). Some experts from Nantucket even deny that Sperm Whales have a brain. Besides having so small a brain, the whale seems to have no nose, no olfactories, and no voice. ${ }^{19} \mathrm{He}$ does not seem to have the power of smelling (p. 982). And as for his ears, they are so astonishingly minuscule that they are hardly detectable. Add to this the fact that he has such disproportionally small eyes and it becomes questionable whether he has any sensitive awareness at all. This huge, black, massive front simply has no face. ${ }^{20}$ The front of the Sperm Whale's head is a dead, blind wall. His tiny eyes are located at either side of his prodigious head. He cannot see the world in front of him. How does he manage to integrate his (extremely restricted) sensitive impressions, or to concentrate on any particular visible item? But then, he spends most of his lifetime in the bottomless deep where utter darkness reigns.

How does the whale experience his world? In what kind of world does he dwell? What is it like to be a whale? ${ }^{21}$ Such are the questions that puzzle Ishmael the philosophical sailor. The whale's world simply seem inaccessible, his experiences unimaginable. We must not forget, of course, that at the time Moby-Dick was written, nothing at all was known about the sonar system or echolocation by means of which whales find their way about, quite unlike anything we humans can experience or imagine. ${ }^{22}$ The nineteenth century sailor was faced with a fundamentally alien form of life. But even with the knowledge of today, it seems utterly impossible for man to experience what a whale experiences - and he might therefore just as well keep his silence, for no vocabulary whatsoever can make this type of worldexperience accessible to us. To a certain extent, the whale can be regarded an "epistemologically privileged being", as it was phrased in Chapter 3, having access to dimensions of the world far beyond our imagination and reach, and developing forms of experience in inaccessible regions that are totally unknown to us. Man simply lacks the $a$ priori conditions for entering or experiencing a whale's world. From a human perspective, the whale's gloomy, silent world seemed an extremely impoverished one. A surviving glimpse of "that shuddering period, ere time itself began, when Saturn's grey chaos swayed through Polar eternities" (p. 1033). On the other hand, the nineteenth century whaler was utterly amazed by the methodical, regular way, the remarkably reliable uniformity with which whales followed their migratory routes amidst the widest expanses of water. ${ }^{23}$ While

\footnotetext{
19 Cetologists nowadays will disagree with this of course. The sperm whale's brains are now considered to be large and complex, even comparable (in terms of size and complexity) to those of primates (Scarff 1980, McIntyre 1974). They are social, communicative animals that produce extremely loud, explosion-like sounds (Kooyman, Norris and Gentry 1975).

20 "How comprehend his face, when he has none? Thou shalt see my back part, my tail he seems to say, but my face shall not been seen" (p. 987). This in contrast to seals, who display an almost human look in their round, peering heads and seemingly intelligent faces (p. 1071). The other extreme is the giant octopus encountered by the Pequod one day: "No perceptible face or front did it have" (p. 927).

21 A similar question is addressed by Thomas Nagel (1974).

22 Ishmael has it that the whale's communicativeness is concentrated in his tail. The peaking of the whale's dignified flukes is perhaps "the grandest sight to be seen in all animated nature" (p. 986). "There are gestures in it, wholly inexplicable, mystic gestures" (p. 987), and there are hunters who declare that through these flukes the whale "intelligently converses with the world" (p. 987).

23 "The hidden ways of the Sperm Whale when beneath the surface remain, in great part, unaccountable to his pursuers; and from time to time have originated the most curious and contradictory speculations regarding them, especially concerning the mystic codes whereby, after sounding to a great depth, he transports himself with such
} 
whaling vessels were sprinkled in a disorderly way over the entire watery circumference, Sperm Whales continued their way along a given ocean-line "with such undeviating exactitude, that no ship ever sailed her course, by any chart, with one tithe of such marvellous precision" (p. 879). ${ }^{24}$ The whale lives "systematically" (p. 982), ascending to the surface at regular intervals, always taking the same number of breaths. The Sperm Whale blows as a clock ticks, with the same undeviating and reliable uniformity (p. 889), as predictable as "the mighty iron Leviathan of the modern railway" (p. 1090).

\section{$\S 5$. And God created great whales: the philosophy of the sublime}

Ishmael's philosophical practices converge into one basic experience, that of the sublime. The very sight of open water already turns him to admire "the magnanimity of the sea which will permit no record" (p. 795) and his prolonged exposure to the unshored, harborless immensities and oceanic expanses only intensifies this experience. The sea, Ishmael tells us, is the anonymous element per se, encompassing everything, but impossible to demarcate. When standing in the mast-head, with a view on the limitless expanses of water around him and his thoughts dwelling on philosophical themes, he experiences the sublime, the astonishing immensity of the world in terms of time and place: Columbus sailed over numberless unknown worlds to discover his one superficial western one (p. 925); Noah's flood is not yet subsided: two thirds of the fair world it yet covers (p. 926).

And yet, apparently, Ishmael has spent enough time in the mast-head, and became enough of a philosopher to understand that the experience of the sublime is not a pure, immediate event, but rather a conditional one. Certain conditions have to be met in order for this experience to occur. If we were to be exposed to the ocean unshielded, we would simply be struck with terror. It is only gradually that man loses his sense of "the full awfulness of the sea which aboriginally belongs to it" (p. 926). The sea is perceived as sublime by us, but our perception is already marked and shaped by certain concepts and ideas. For one thing, it is prerequisite that, up there in the mast head for instance, we feel reasonably safe, that we somehow stand above it. Under such conditions, a sailing philosopher may not "feel one whit more of terror than though seated before your evening fire" (p. 930). The basic element (water, fire) has been subdued by human technology: still fascinating, but no longer terrifying. Yet, the real sea, experienced immediately so to speak, is simply terrible - a masterless commotion. Man is alien to it. "No mercy, no power but its own controls it. Panting and snorting like a mad battle steed that has lost its rider, the masterless ocean overruns the globe. Her creatures carrying on an eternal war since the world began. Consider all this..." (p. 926). When seen from the mast-head, the ocean appears sublime, but when Ishmael, at the time of the final catastrophe, suddenly finds himself floating in the middle of the ocean, with no sign of humanity in sight, then the ocean is still enormous and immense, but utterly terrifying. Under such conditions, the experience of the sublime has completely vanished and is replaced by sheer terror and despair. The ocean now seems nothing but

vast swiftness to the most widely distant points... The Nor'West Passage, so long a problem to man, was never a problem to the whale" (p. 869).

24 "So assured, indeed, is the fact concerning the periodicity of the sperm whale's resorting to given waters", Ishmael tells us, "that many hunters believe that, could he be closely observed and studied throughout the world; were the logs of one voyage of the entire whale fleet carefully collated, then the migrations of the sperm whale would be found to correspond in invariability to those of the herring-shoals or the flight of swallows. On this hint, attempts have been made to construct elaborate migratory charts of the sperm whale" (p. 878). 
emptiness, and the one time philosopher becomes a perishable living being, about to disappear in the frightful abyss without a trace. "The wild, the watery and the unshored" (p. 1050 ) is $\delta \varepsilon i v o \varsigma$ beyond comparison, it is pure indifference, referred to by Levinas as the il $y$ $a$, a world disappearing in darkness, utterly insensitive to human suffering. It is the dreadful sea as it emerges in the dream reported by Clarence in Shakespeare's King Richard the Third, about stumbling, or being pushed, overboard, "into the tumbling billows of the main: / Lord, Lord! methought what pain it was to drown". The same indifference is signified by the Sperm Whale, - the animal without a face. The sublime is an experience that will occur under the condition that we somehow remain part of the human world.

To what extent can Ishmael's meditations on the sublime be considered Kantian? At first glance, both authors seem to refer to, and to be fascinated by, one and the same basic image. Indeed, one could say that, while Kant's Critiques (notably the first two) are so utterly dominated by the formal, discursive mode of thought, his phenomenology of the sublime is remarkably imaginative, "un-Kantian" perhaps, guided by and responsive to an elementary image. ${ }^{25}$ The ocean, Kant tells us, is called sublime - erhaben - because the idea of infinity is conveyed by it, but certain conditions have to be met in order for such an experience to occur at the sight of something which, if experienced as such, could only produce in us fear and abhorrence. ${ }^{26}$ So far, Kant and Ishmael seem to agree.

Moreover, not only to the sea itself, but also its most eminent inhabitant, the whale, seems to evoke this experience of the sublime. According to Kant, the mathematically sublime refers to that which is immeasurable and great "beyond comparison", 27 and these are precisely the terms in which the experience of spotting living whales is articulated by Ishmael. In a quotation he extracted from a book on natural history it is said that "if we compare land animals in respect to magnitude, with those that take up their abode in the deep, we shall find they will appear contemptible in the comparison. The whale is doubtless the largest animal in creation" (p. 753). Indeed, chief among Ishmael's motives for going to sea was "the overwhelming idea of the great whale himself" (p. 762). On entering a whaler's inn, he discerns on a primitive, soot-coloured painting of a black mass of "unimaginable sublimity" - a whale. The Sperm Whale is referred to as "the mightiest animated mass that has survived the flood; most monstrous and most mountainous! That Himmalehan, salt-sea Mastodon, clothed with such portentiousness of unconscious power... Living in the bottomless deep..." (p. 797). He is, without doubt, "the largest inhabitant of the globe; the most formidable of all whales to encounter; the most majestic in aspect..." (p. 840). Leviathan is of a mighty magnitude. The most imposing view to be had is that of the full front of his head: this aspect is "sublime" (p. 967). When hunting the whale, the whaler competes with what seems grand beyond comparison, a mighty monster, absorbed in incommunicable

\footnotetext{
25 "So kann der weite, durch Stürme emporte Ozean nicht erhaben genannt werden. Sein Anblick ist grässlich; und man muss dat Gemüt schon mit mancherlei Ideen angefüllt haben, wenn es durch eine solche Anschauung zu einem Gefühl gestimmt werden soll, welches selbst erhaben ist... Wer wollte auch ... die düstere tobende See erhaben nennen?... Der grenzenlose Ozean, in Empörung gesetzt... [I]hr Anblick wird nur um desto anziehender, je furchtbarer er ist, wenn wir uns nur in Sicherheit befinden..."

26 Cf. Nietzsche: "Now, little ship, look out! Beside you is the ocean: to be sure, it does not always roar, and at times it lies spread out like silk and gold and reveries of graciousness. But hours will come when you will realize that it is infinite and that there is nothing more awesome than infinity" $(1974, \S 124)$.

27 Ishmael, visiting a whale's skeleton worshipped by the inhabitants of an island, marvels, but also seized the opportunity for doing some anatomical research. How now!, the priest shouted, "Dar'st thou measure this our god!" (p. 1030). Here, apparently, Ishmael is doing what on other occasions he blames scientists to do, namely reducing the sublimity of the whale to quantitative data. It also shows Ishmael's flexibility in terms of methodology. He may occasionally resort to more or less scientific methods.
} 
contemplations, an animal of "great inherent dignity and sublimity", both ponderous and profound (p. 984). His head is comparable to "Melanchthon's forehead" (p. 968), but in the great Sperm Whale, the "high and mighty godlike dignity inherent in the brow is so immensely amplified, that gazing on it, in that full front view, you feel the Deity and the dread powers more forcibly than in beholding any other object in living nature" (idem). The grandeur of his head incites the idea of genius. "But how? Genius in the Sperm Whale? Has the Sperm Whale ever written a book, spoken a speech? No, his great genius is declared in his doing nothing particular to prove it. It is moreover declared in his pyramidical silence" (968). ${ }^{28}$ In Moby-Dick, the Sperm Whale is described by the very images Kant himself uses to allude to the sublime: pyramids, Saint Peter's Dome.

Yet, according to Kant, eventually we must recognise that neither the ocean itself, nor the whale as such should be regarded as sublime. Rather, he follows Sophocles: more overwhelming even than nature is man. The experience of the sublime eventually refers to our own ability to conquer and subdue maritime nature. For Ishmael, this cannot be true. The sea itself, and the whale itself remain what is truly sublime and we become insignificant in comparison with it. Although we slaughter whales, Ishmael seems to believe that we cannot really destroy these animal as such, not their basic image or idea. The pre-Adamite whale survived the great Deluge without the help of man, and dwells ever since in an antediluvian world unknown to us. He steered clear of the Ark, went his own way, survived the Flood by becoming a sea animal. In that wondrous period, the gloomy epoch of Saturn, all the world was the whale's (p. 1033), when in shuddering polar eternities he lived his undocumented life. He is the gliding great demon in the seas of life, defying the unimaginable cold and blackness of the deep. As an apparition, in his full terribleness, when breaching from the farthest depths, the Sperm Whale is of all cetacean the most sublime, inspiring both awe and wonder, and the list of names for the whale in thirteen languages with which Ishmael begins his cetological account reads like a series of incantations, pronounced in order to adjure something terrible. He is marvellously adapted to the most extreme of circumstances, but at the same time out of place, both as a sea-dwelling mammal and as the sole survivor of the prehistoric monsters that roamed the earth in distant times. In the end, all efforts to represent the whale's sublimity are bound to fall short. Not only will his life remain unwritten, he is also, as we have seen, that one creature in the world that must remain unpainted to the last. No portrait can hit the mark with any considerable degree of exactness (p. 921). A painting will be most like a whale when it is difficult to imagine that this really is what his living contours look like. ${ }^{29}$

But Moby-Dick is not an unequivocal monologue on sublimity. Ishmael both mocks and venerates the whale, for example when he points out that the absence of a nose is a deficiency that only adds to the animal's grandeur. Moreover, in spite of all veneration, whales are still being captured, hoisted and butchered, and their bodies are ruthlessly desecrated in the course of a demolishing procedure during which every trace of dignity is completely erased. One whale, about to be captured, is said to produce "an enormous wallowing sound as of fifty elephants stirring in their litter" (p. 895). A red tide pored from all sides of another gigantic whale, whose tormented body wallowed in a crimson pond,

\footnotetext{
28 More sublime than any other whale is of course Moby-Dick himself: "Not the white bull Jupiter... not Jove, not that great majesty Supreme! did surpass the glorified White Whale as he so divinely swam" (p. 1086).

$29 \mathrm{Cf}$. Wolf, 1986. One illustration, although calculated to excite the scepticism of landsmen, is judged by Ishmael as "admirably correct and lifelike in its general effect" (p. 921). But Captain Scoresby, in his eagerness no doubt to comply with the epistemological principles of science, drew his pictures on too small a scale to convey the desirable impression.
} 
abating in his flurry, while spasmodically dilating and contracting his spout-hole, until finally "gush after gush of clotted red gore shot into the frighted air" (p. 932/3). Like Dionysos himself, the great whale - "that big god aloft there somewhere in yon darkness" (p. 866) - is cut to pieces in the end. "Every whaler is a butcher" (p. 942), involved in a bloody, greasy business, using whales as raw material for his trade, spilling tonnes of Leviathanic matter. They constitute the rank and file in an appalling and uneven battle between the technologically-equipped bipeds of industrial society and the giant but defenceless mammals of ante-deluvian nature. One of the Pequod's crew members is said to be so utterly lost to all sense of reverence for the whale's majestic bulk and mystic ways, that in his poor opinion, "the wondrous whale was but a species of magnified mouse" (p. 830). The experience of sublimity can easily give way when man finds his inferiority in terms of bulk and physical strength more than compensated by his superiority in terms of technical equipment and cunning.

This struggle between veneration and disregard also applies to the ocean as such. Yet, as in the case of Moby-Dick, maritime nature ultimately gets the best of it. Eventually, the human world is shown to be only a transitory phenomenon. Barometers, quadrants, charts and other equipment cannot subdue the helplessness and fragility of humanity before the shrieks of the ocean and the madness and gladness of her demonic waves. It is certainly no coincidence that, shortly before his fatal encounter with Moby-Dick, Ahab destroys his quadrant, shouting: "Science! thou vain toy!" (p. 1058). In the end, all collapses, "and the great shroud of the sea rolled on as it rolled five thousand years ago" (p. 1102). Melville's masterpiece not only addresses the issue of the disappearance of whales. His novel is also about the inevitable disappearance, sooner or later, of man himself. Melville seems to take a "grim pleasure" in showing our insignificance before the magnitude of nature (Kazin 1960, p. 59). Moby-Dick constitutes an attempt to present us with nature as it might be conceived with man entirely left out. In the end, all that is left is the trackless, fathomless "nothing" that has been there from the beginning, a beginning that just was, with no one present either to deplore the extinction, or to rejoice at the survival, of magnificent species such as the whale, or humankind. And no doubt, as we disappear, it will seem as if all these events have never happened, as human beings are no longer available to record their traces. ${ }^{30}$

\section{$\S 6$. Will the whale perish? The ethics of Moby-Dick}

In Moby-Dick whaling is perceived as a highly dubious animal practice. To the whaler, the whale is either an object of exploitation (the whaler as a butcher) or an opponent in a contest (the whaler as a hunter). To Ishmael's mind, however, the scientist's objective is no less disturbing. For science aims at reducing the unknown to the known. Thus, the living animal becomes a lifeless object. By dissecting the whale, by harming his vitality, his dignity and integrity, science hopes to put him in his zoological place. Apparently, it is only the philosopher, or rather the philosophical sailor, who appreciates the inherent dignity and sublimity of the whale. But there is a prize to be paid: this philosophical upgrading of the whale seems to rest on mystification and idealization. ${ }^{31}$

That there are certain drawbacks to Ishmael's idealistic overestimation of the whale,

30 Cf. Nietzsche: "Es gab Ewigkeiten, in denen der Mensch nicht war; wenn es wieder mit ihm vorbei ist, wird sich nichts begeben haben" (Über Wahrheit und Lüge im außermoralischen Sinne, 1873, Nachlaß).

31 See for example Ishmael's denial of the fact that the breath of a whale is attended with an "insupportable smell" (p. 752). 
becomes clear when the question whether the whale will eventually perish is explicitly addressed (Chapter 105). Can Leviathan long endure so wide a chase? Will he not at last be exterminated from the waters? Can he escape speedy extinction? Ishmael agrees that the prospects seem disquieting, especially if we look at the vicissitudes of other large species: "Though so short a period ago - not a good lifetime - the census of buffalo in Illinois exceeded the census of men now in London, at the present day not one horn or hoof of them remains in all that region..." (p. 1035). Will not the whale befall a similar fate? Here, however, the sailing Platonist assures us that this will not be the case. The waning whale can always resort to its eternal December in some polar citadel, impenetrable to man. "We account the whale immortal in his species, however perishable in his individuality" (p. 1037). He despised Noah's ark, and if ever the world is to be again flooded, the eternal whale will still survive.

But present-day readers may not that easily be reassured. Rather, we tend to rely upon scientific research to provide us with statistics and facts. After carefully counting whales and diligently monitoring populations, scientists will tell us that the prospects are rather bleak. In the middle of the nineteenth century, a sensitive whaler could perhaps still afford to calm his presentiments with the help of platonic reflections on the imperishability of such an amazing species, - of the indestructibility of whales as a basic image or idea -, but nowadays the whale has finally entered the Ark, that is: the sphere of human responsibility, and it is only by an active policy of protection that the shrinking "herds" of ante-diluvian monsters may be preserved.

Yet, as a novel, Moby-Dick basically deals with epistemological problems of representation rather than with ethical issues of extinction. Moby-Dick analyzes a number of epistemological strategies for perceiving and describing whales. In the case of the sailorphilosopher, the strategy used is idealization. Notwithstanding the poetic beauty of the panegyrics that at times descend from Ishmael's idyllic mast-head, they serve an ideological function insofar as they do not interfere with the brutal butchering that is going on at sealevel and on deck. While calmly reflecting on the platonic, idealized whale, the real whale is allowed to extinguish. A similar ideological function can be discerned in some the poetic, Biblical metaphors employed by the Pequod's whaling crew, while in their very hands, the mysterious whale is speedily transformed into the raw material of their grubby trade.

Nineteenth century scientists may well fall short in doing justice to the living experience of the living whale, and may well have failed to keep their objects alive and intact, but their dissecting practices (usually of stranded whales) constituted a much more refined form of demolition than those of whaling proper.

What we may learn from Moby-Dick, insofar as ethics is concerned, is that our position on moral issues depends on our epistemological stance and on the epistemological nature of the sources we rely on in answering the question "What is a whale?" As for the issue of extinction, the Pequod's crew, much like their modern colleagues, seem utterly unaffected by such a prospect, while the philosopher's stance in Moby-Dick is one of disavowal and denial. In Melville's time the scientific knowledge concerning whales was too limited to be of much help in this matter, while modern scientists may take various positions. While some of them provide us with disquieting statistics, others argue that extinction is a natural phenomenon and whales are apparently an evolutionary dead end (Cf. Slijper 1962).

\section{$\S 7$. Concluding remarks}


This chapter was devoted to a case study: the epistemological significance of one of the most important animal novels ever written. In Chapter 2 it was indicated that, for centuries, the literature on animals has been dominated by two very influential genres: the "history of animals" tradition, initiated by Aristotle and based on dissection and binary classifications, and the fable literature, relying on remarkably stable and typical images of animals. In the nineteenth century, in Darwin's era, a much more realistic approach emerged in literature, philosophy and science. Animals suddenly became alive so to speak.

Interestingly, in Moby-Dick all these lines of development seem to converge. First of all, as a fabulous animal, a kind of sea monster, the great white whale seems to adhere to and revivify the fable literature. On the other hand, practices of classification are emphatically present and fiercely discussed. Sometimes, Ishmael himself reverts to techniques of classification and dissection, investigating the remains of stranded whales for instance, or describing their brains and sense organs with some precision, while on other occasions he firmly rejects these techniques as inadequate. That is: the time-old tension between "science" and "literature", between classification and imagination, as two basic epistemological orientations when it comes to knowing animals is fleshed out in a polemical manner in this novel. Which of the two will prove a dead end? Which of the two will show itself to be the fittest approach in this epistemological "struggle for survival"? Ishmael's decision to align himself with the whaler's whale, so overtly loaded with the logic of the fabulous, does not seem a very promising option, from an epistemological point of view that is. Melville's book contains a very realistic version of both traditions, however. The whale as an animal is no longer a type or caricature, it is no longer an anatomical oddity, but really seems to come alive.

The next chapter will likewise be devoted to practices of dissecting and demolishing living animals, but in a rather different context. In Moby-Dick, science was predominantly represented by practices of classification and taxonomy. In the course of the nineteenth century, however, the experimental approach became increasingly important. Evolution theory and experimentation are the two manifestations of realism in biology, counterparts of the realistic novel. That is why, in the next chapter, the focus will shift from classification as a scientific "animal practice" to experimentation. In terms of species, the focus will be on experiments with dogs. In the case of Moby-Dick we started with the literary document and looked at scientific discourses from that perspective. In the next chapter a different approach will be taken. First of all, we will describe the emergence (notably during the second half of the nineteenth century) of realism in both science and literature. Subsequently, we will focus on scientific discourse (animal experiments, notably dog physiology), while the final sections are devoted to its literary counterparts (notably the dog novel). 